\title{
Analisis Pembentukan Harga Komoditas Cabai Rawit dan Bawang Merah Pada Tingkat Eceran di Kota Ambon
}

\section{The Analysis on Formation of Prices of Cayenne and Shallot Commodities at Retail Levels in Ambon City}

\author{
Natelda R. Timisela ${ }^{1, *}$, Yuliahwati E. Salampessy ${ }^{2}$, Yolanda M.T.N. Apituley ${ }^{3}$ \\ ${ }^{1}$ Jurusan Sosial Ekonomi Pertanian, Fakultas Pertanian, Universitas Pattimura, Jln. Ir. M. Putuhena, Kampus Poka \\ Ambon, 97233 Indonesia \\ ${ }^{2}$ Dinas Pertanian dan Ketahanan Pangan Kota Ambon, Jln. Sultan Hairun No.1 Ambon, Indonesia \\ ${ }^{3}$ Jurusan Agrobisnis Perikanan, Fakultas Perikanan dan Ilmu Kelautan, Jln. Mr. Chr. Soplanit, Poka, Teluk Ambon, \\ Kota Ambon 97233 Indonesia \\ *E-mail Penulis Korespondensi: natelda.timisela@ faperta.unpatti.ac.id
}

Tanggal submisi: 21 November 2019; Tanggal penerimaan: 27 April 2020

\begin{abstract}
The distribution channel is one of the significant factors that influence the price formation of a commodity. This research intended to analyze several factors that affect the price formation of cayenne and shallot at the retail level in Ambon City. The data collected in this research were primary and secondary. The samples used in this research consisted of 30 respondents of each commodity (shallot and cayenne), and eight people from each marketing agency or distributors (wholesalers, distributors, and retailers). The collected data were analyzed by applying Multiple Linear Regression analysis. The result of the research depicted that factors that influenced the price formation of cayenne at the retail levels were transportation $\left(X_{1}\right)$, the packaging $\left(X_{3}\right)$, the difference between in supply and demand $\left(X_{5}\right)$, while that factors that influence the price formation of shallots at the retail levels were transportation $\left(X_{1}\right)$, the difference between in supply and demand $\left(X_{5}\right)$, production $\left(X_{6}\right)$, and substitution goods $\left(X_{7}\right)$.
\end{abstract}

Keywords: cayenne, shallot, price, retail

\section{ABSTRAK}

Saluran distribusi merupakan salah satu faktor yang mempengaruhi pembentukan harga suatu komoditas. Penelitian bertujuan untuk menganalisis faktor-faktor mempengaruhi pembentukan harga cabai rawit dan bawang merah ditingkat eceran di Kota Ambon. Sampel penelitian adalah pengecer komoditi bawag merah dan cabe rawit berjumlah masing-masing 30 responden. Analisis data menggunakan analisis regresi linear berganda. Hasil penelitian menunjukkan bahwa faktor-faktor yang memengaruhi pembentukan harga cabai rawit di tingkat eceran adalah transportasi $\left(X_{1}\right)$, kemasan $\left(X_{3}\right)$ dan selisih pasokan dan permintaan $\left(X_{5}\right)$, sedangkan faktor-faktor yang mempengaruhi pembentukan harga bawang merah di tingkat eceran adalah transportasi $\left(X_{1}\right)$, selisih pasokan dan permintaan $\left(X_{5}\right)$, produksi $\left(X_{6}\right)$, dan barang substitusi $\left(X_{7}\right)$.

Kata Kunci: bawang merah, cabai rawit, harga, eceran

\section{PENDAHULUAN}

Peningkatan daya saing komoditi pertanian sangat penting dalam menghadapi persaingan di pasar nasional maupun internasional. Jaminan kesinambungan atas kualitas produk, jumlah pasokan yang relatif minim, waktu pengiriman yang belum tepat serta kinerja rantai pasok yang belum efektif dan efisien semuanya merupakan kendala dari komoditi pertanian saat ini. Tujuan pengukuran kinerja adalah untuk merancang tujuan, mengevaluasi kinerja dan ditemukan adanya langkah yang baik kedepan pada tingkatan strategi, operasional dan taktik (Van der Vorst, 2004).

Sifat produk pertanian adalah cepat rusak, proses panen tergantung musim, banyak variasi dan tidak tahan simpan. Terdapat produk yang mengalami kesulitan dalam pengangkutan dan pengelolaan karena berukuran besar serta sifat produk yang kompleks. Dua komoditi pertanian yang menjadi primadona untuk diperdagangkan adalah bawang merah dan cabai rawit. Kedua komoditi ini dikonsumsi masyarakat tanpa memperhatikan tingkatan sosial. Umumnya masyarakat 
mengkonsumsi bawang berah dan cabai rawit sebagai bumbu rnasak atau dalam bentuk segar. Cabai rawit dan bawang merah dinilai cukup penting sebagai penyedia gizi masyarakat.

Umumnya cabe bernilai gizi tinggi seperti vitamin A, B dan C, protein, lemak, karbohidrat, kalori, kalsium, untuk pemenuhan kebutuhan konsumsi keluarga dan cabe sebagai bahan baku kebutuhan industri seperti makanan, bumbu masakan, obat-obatan maupun jamu (Setiadi, 2008). Selain cabe, bawang merah juga tidak kalah penting karena mengandung nutrisi, vitamin B6, kalium dan vitamin $\mathrm{C}$ yang diperlukan oleh tubuh (Hidayat, 2013). Bawang merah dan cabe rawit dibutuhkan masyarakat Indonesia sehingga permintaannya meningkat sekalipun harga fluktuatif. Bawang merah dan cabe mempunyai harga yang berfluktuasi disebabkan sifat produk pertanian dalam hal ini bawang merah dan cabe yang cepat rusak atau membusuk (Ariningsih dan Tentamia, 2004).

Sejalan dengan laju pertumbuhan penduduk terlihat bahwa kebutuhan dan konsumsi bawang merah dan cabai rawit dalam masyarakat setiap waktu terus meningkat. Periode 2002-2018 terlihat bahwa konsumsi cabe rawit fluktuatif. Konsumsi cabe rawit tahun 2002 sebesar 1.126 kg/kapita. Tahun 2018 mengalami peningkatan sebesar $1.835 \mathrm{~kg} / \mathrm{kapita}$, terjadi kenaikan sebesar 7,53\%. Periode 2019-2021 diprediksi bahwa konsumsi cabe rawit akan terus mengalami peningkatan hingga mencapai $1,850 \mathrm{~kg} / \mathrm{kapita}$ atau terjadi kenaikan sebesar $0,78 \%$.

Periode 2002-2021 konsumsi rumah tangga terhadap bawang merah fluktuatif dan terus meningkat untuk tahun berikutnya. Tahun 2007 konsumsi bawang merah mencapai 3,014 kg/kapita/tahu atau 44,50\%. Tahun 2014 konsumsi mencapai 2,487 kg/kapita/tahun atau sebesar 20,44\%. Tahun 2012 konsumsi mencapai $2,764 \mathrm{~kg} / \mathrm{kapita} / \mathrm{tahun}$ atau $17,00 \%$. Tahun 2013 konsumsi terendah 2,065 kg/kapita/tahun. Tahun 2017 konsumsi 2,570 kg/kapita/tahun dan mengalami penurunan $9,05 \%$. Tahun 2018 konsumsi sebesar 2,764 $\mathrm{kg} / \mathrm{kapita} / \mathrm{tahun}$, mengalami peningkatan $7,52 \%$. Diprediksikan bawang merah akan meningkat pada tahun 2019-2021. Tahun 2019 konsumsi meningkat 2,796 $\mathrm{kg} / \mathrm{kapita} / \mathrm{tahun}$ atau naik $1,18 \%$. Tahun 2020 konsumsi sebanyak 2,832 kg/kapita/tahun atau 1,28\% menaik dari tahun sebelumnya. Tahun 2021 konsumsi meningkat menjadi $2,867 \mathrm{~kg} / \mathrm{kapita} / \mathrm{tahun}$ atau menaik $1,25 \%$ dari tahun 2020 (Sabarella et al., 2019).

Kecenderungan terjadinya peningkatan kebutuhan, tetapi permintaan terhadap bawang merah dan cabai rawit fluktuatif karena harga di pasar eceran tidak stabil. Harga fluktuatif disebabkan oleh faktor pendapatan, populasi, harga barang substitusi dan selera yang mempengaruhi permintaan. Faktor yang mempengaruhi penawaran antara lain harga faktor produksi, harga barang lain, harapan produsen, dan jumlah produsen. Keseimbangan harga terjadi pada kondisi penawaran sama dengan permintaan. Apabila harga bawang merah dan cabe rawit turun, maka jumlah permintaan banyak. Sebaliknya apabila harga naik maka permintaan sedikit. Berbeda dengan sisi produsen, harga naik maka penawaran meningkat namun apabila harga turun maka penawaran menurun. Oleh sebab itu perlu menjaga keseimbangan harga supaya konsumen akan memperoleh jumlah pembelian sesuai harga yang berlaku. Hal ini terjadi pada produsen yakni mereka akan menjual menawarkan produk ke pasaran sesuai harga yang berlaku.

Proses pembentukkan harga suatu komoditas umumnya ditentukkan oleh banyak faktor, salah satunya adalah pengaruh saluran distribusi. Hal ini dikarenakan adanya perbedaan biaya pada lembaga pemasaran. Faktor-faktor pembentukan harga antara lain gangguan distribusi, biaya transportasi, rantai pasokan dan margin keuntungan di setiap rantai pasok (Prastowo et al., 2008).

Harga komoditi yang diterima konsumen akhir tergantung pada saluran pemasaran yang terbentuk (Prastowo et al., 2011). Semakin panjang saluran pemasaran cabai dan bawang merah, maka harga akan menaik dan sebaliknya. Hal ini memungkinkan terjadinya pembentukan harga di tingkat konsumen akhir (Ruslan, 2016). Ditingkat petani, harga bawang merah terbentuk berdasarkan proses tawar-menawar (Putri, 2016). Disisi lain Wahyudi et al. (2018) menemukan bahwa penentuan harga cabai ditentukan oleh pengepul.

Permintaan cabe rawit dan bawang merah di Maluku sangat signifikan. Setiap hari selalu terjadi peningkatan permintaan terhadap kedua komoditi tersebut. Pemasok kedua komoditi tersebut di Kota Ambon adalah produsen di Maluku dan distributor luar Maluku. Harga kedua komoditi ini selalu berfluktuasi. Hal ini disebabkan jika ketersediaan cabe rawit dan bawang merah meningkat maka harga akan turun dan sebaliknya. Harga komoditas ditentukan oleh tengkulak atau pedagang bawang merah dari produsen ke konsumen (Soepatini et al., 2017). Pembentuk harga yang paling dominan untuk bawang merah adalah biaya transportasi (Soepatini et al., 2017). Untuk komoditi cabai rawit, permintaannya dipengaruhi oleh harga (Palar et al., 2016). Tujuan penelitian untuk menganalisis faktor-faktor yang mempengaruhi pembentukkan harga komoditas bawang merah dan cabai rawit.

\section{METODE PENELITIAN}

Penelitian berlokasi di Kota Ambon. Sampel penelitian ditentukan secara simple random sampling terhadap pedagang pengecer. Terdapat 60 responden, masing-masing terdiri dari 30 pedagang pengecer komoditi bawang merah dan 30 pedagang pengecer komoditi cabe rawit. Data penelitian dianalisis secara kualitatif dan kuantitatif. Analisis kualitatif untuk menggambarkan karakteristik responden dan rantai pasar. Sedangkan analisis kuantitatif untuk menganalisis faktor-faktor pembentuk harga menggunakan regresi linear berganda.

$$
P_{e}=X_{1}+X_{2}+X_{3}+X_{4}+D+\varepsilon
$$

Keterangan: $\mathrm{P}_{\mathrm{e}}=$ harga bawang merah dan cabe rawit di tingkat eceran; $X_{1}=$ biaya transportasi; $X_{2}=$ retribusi; $X_{3}$ 
= kemasan; $X_{4}=$ Selisih Pasokan dan permintaan cabe rawit dan bawang merah; $X_{5}=$ produksi; $X_{6}=$ barang substitusi; dan D = Dummy Gangguan Distribusi atau cuaca buruk; $e=$ error term.

\section{HASIL DAN PEMBAHASAN}

\section{Profil Responden}

Berdasarkan kategori umur, responden termasuk umur produktif yaitu 15-64 tahun sebesar $100 \%$. Tingkatan pendidikan responden didominasi pada jenjang SMA sebesar 70\%. Jumlah anggota keluarga (JAK) responden tergolong keluarga kecil yakni 1-4 orang sebesar $68,33 \%$. Pengalaman usaha dagang termasuk dalam kategori $<5$ tahun sebesar 48,33\%. Tabel 1 menunjukkan profil responden berdasarkan tingkat pendidikan, umur, JAK dan pengalaman usaha.

Karakteristik menunjukkan kemampuan, pengetahuan, kualitas, kuantitas dan kekuatan untuk melakukan usahanya. Dorongan dan pikiran yang sehat serta kondisi fisik yang baik sangat berpengaruh terhadap perkembagan usaha. Karakteristik responden lainnya yakni berkaitan dengan usaha, meliputi sistem penentuan harga jual dan pihak yang paling dominan dalam penentuan harga jual. Penentuan harga jual untuk kedua komoditi (cabai rawit dan bawang merah) didasarkan pada harga pasar yang berlaku dan disesuaikan dengan harga penjual/pemasok. Pedagang pengecer rata-rata berusia produktif. Hal ini dikarenakan setiap hari mereka menjalankan aktivitas di pasar yang sangat membutuhkan tenaga ekstra untuk berdagang. Terlihat bahwa pedagang berumur produktif sangat energik untuk menawarkan produk yang dijual ke konsumen. Mereka harus mampu menarik pelanggan sebanyak-banyaknya untuk membeli barang daganganya. Oleh sebab itu usia sangat menentukan maju mundurnya usaha dagang yang dilakoni.

Tingkat pendidikan pedagang bawang merah dan cabe rawit adalah SMA. Pendidikan menjadikan pribadi seseorang semakin baik untuk berproses. Pendidikan tidak menjadi jaminan untuk seseorang berdagang. Karena tingkatan pendidikan apapun dibarengi dengan pengalaman maka usaha akan berjalan baik. Pengalaman usaha dagang lebih banyak $<5$ tahun dan 5-10 tahun. Pengalaman dagang sangat baik karena pedagang sudah banyak mengetahui hiruk pikuknya usaha berdagang. Setiap hari mereka bertemu dengan sesama pedagang dan konsumen di pasar dengan beraneka ragam perilaku. Pengalaman ini diperoleh turun temurun dari keluarga yang sehari-hari bekerja sebagai pedagang di pasar. Mereka terus berusah untuk meningkatkan kualitas dan kuantitas produk yang dipasarkan dan tetap menjaga pelanggan/konsumen akhir supaya tercipta kepercayaan dan kerjasama yang baik.

\section{Mekanisme Pembentukan Harga}

Harga barang merupakan nilai tukar barang yang dinyatakan dalam bentuk uang (Hanafiah dan Saefuddin 2006). Harga merupakan hal yang menarik bagi penjual dan pembeli. Pada saat terjadi transaksi barang maka harga terbentuk, selisih antara harga dan biaya menentukan keuntungan yang diterima pedagang. Harga yang diterima konsumen sebagai sebuah konsekwensi terhadap jumlah barang yang dibeli, mutu dan jenis. Besaran uang yang dibayarkan konsumen untuk pengadaan suatu barang menjadi pertimbangan terhadap jasa yang diterima.

Tabel 1. Karakteristik responden

\begin{tabular}{|c|c|c|c|}
\hline \multirow{2}{*}{ Karakteritik Responden } & \multirow{2}{*}{ Karegori } & \multicolumn{2}{|c|}{ Pedagang Pengecer } \\
\hline & & Jumlah (Orang) & Persentasi (\%) \\
\hline \multirow[t]{2}{*}{ Umur } & 15-64 Tahun (Produktif) & 60 & 100,00 \\
\hline & Total & 60 & 100,00 \\
\hline \multirow{5}{*}{ Tingkat Pendidikan } & Tidak Tamat SD & 4 & 6,67 \\
\hline & SD & 4 & 6,67 \\
\hline & SMP & 10 & 16,67 \\
\hline & SMA & 42 & 70,00 \\
\hline & Total & 60 & 100,00 \\
\hline \multirow[t]{4}{*}{ Jumlah Anggota Keluarga } & 1-4 Orang (Kecil) & 41 & 68,33 \\
\hline & 5-7 Orang (Sedang) & 17 & 28,33 \\
\hline & > 7 Orang (Besar) & 2 & 3,33 \\
\hline & Total & 60 & 100,00 \\
\hline \multirow[t]{4}{*}{ Pengalaman Usaha } & $<5$ Tahun (Kurang) & 29 & 48,33 \\
\hline & 5-10 Tahun (Cukup) & 25 & 41,67 \\
\hline & >10 Tahun (Pengalaman) & 6 & 10,00 \\
\hline & Total & 60 & 100,00 \\
\hline
\end{tabular}

Sumber: Data Analisis (Salampessy et al., 2019). 
Hasil penelitian menujukkan bahwa pembentukan harga jual oleh petani cabai rawit dan bawang merah merupakan hasil negosiasi antara pedagang dan petani di Kota Ambon. Proses penentuan harga jual oleh petani cabai rawit dan bawang merah didasarkan pada harga yang berlaku di pasar. Harga jual ditentukan awalnya oleh petani cabai rawit dan bawang merah, selanjutnya proses negosiasi berlangsung dengan pedagang pengumpul dan distributor yang membeli cabai rawit dan bawang merah.

Proses negosiasi, pedagang pengumpul dan distributor sebagai dasar untuk menentukan kesediaan dalam melakukan pembelian. Meskipun dalam proses negosiasi ada kesepakatan harga, namun pedagang yang membeli cabai rawit dan bawang merah lebih mendominasi dalam penentuan harga. Dengan kata lain petani cabai rawit dan bawang merah masih bertindak sebagai price taker, sementara pedagang pengumpul dan distributor yang membeli dari petani bertindak sebagai price maker.

\section{Pemasaran Komoditi Cabai Rawit dan Bawang Merah}

Penelitian menunjukkan bahwa terdapat lima Rantai pasar terhadap dua komoditi yang diperdagangkan di Kota Ambon yang ditampilkan pada Gambar 1. Rantai pasar ke-4 dan ke-5 merupakan distribusi dari luar Maluku. Proses ini terjadi supaya stok kedua komoditi tetap tersedia untuk memenuhi permintaan konsumen. Jika sewaktu-waktu jumlah stok dalam Maluku tidak mencukupi maka stok dari luar yang akan menutupi kekurangan tersebut. Selain itu, harga jual kedua komoditi menjadi pertimbangan karena harga jual dari luar lebih murah dibandingkan harga lokal.

Persediaan bawang merah dan cabe rawit dari luar Maluku biasanya untuk menyokong permintaan konsumen yang meningkat pada hari besar keagamaan dan acara-acara lainnya seperti hari raya idul fitri, natalan, tahun baru, acara sidi, acara wisuda dan lainnya. Pasokan dari petani lokal belum mencukupi permintaan konsumen. Terkadang harga kedua komoditi akan tinggi pada saat terjadi kekurangan stok. Oleh sebab itu untuk menjaga supaya harga tetap stabil maka diperlu pasokan dari luar daerah. yaitu Surabaya, Makasar, dan Manado.

\section{Margin Pemasaran}

Perbedaan harga yang dibayar pembeli terakhir dan harga yang dibayar kepada penjual pertama dikenal sebagai margin pemasaran (Hanafiah dan Saefuddin, 2006). Berdasarkan hasil penelitian, pada rantai pasar I (petani - konsumen), laba petani cabai sebesar Rp $47.586 / \mathrm{kg}$, sementara keuntungan yang diperoleh petani bawang merah yakni Rp 28.553/kg. Jenis biaya yang dikeluarkan responden adalah biaya pembelian kemasan karung.

Margin pemasaran sebesar $\mathrm{Rp}$ 0,- hal ini dikarenakan tidak ada selisih harga untuk penyaluran kedua komoditi dari produsen ke konsumen. Di sisi lain, keuntungan cukup tinggi diperoleh pada rantai pasar I karena rendahnya biaya pemasaran.

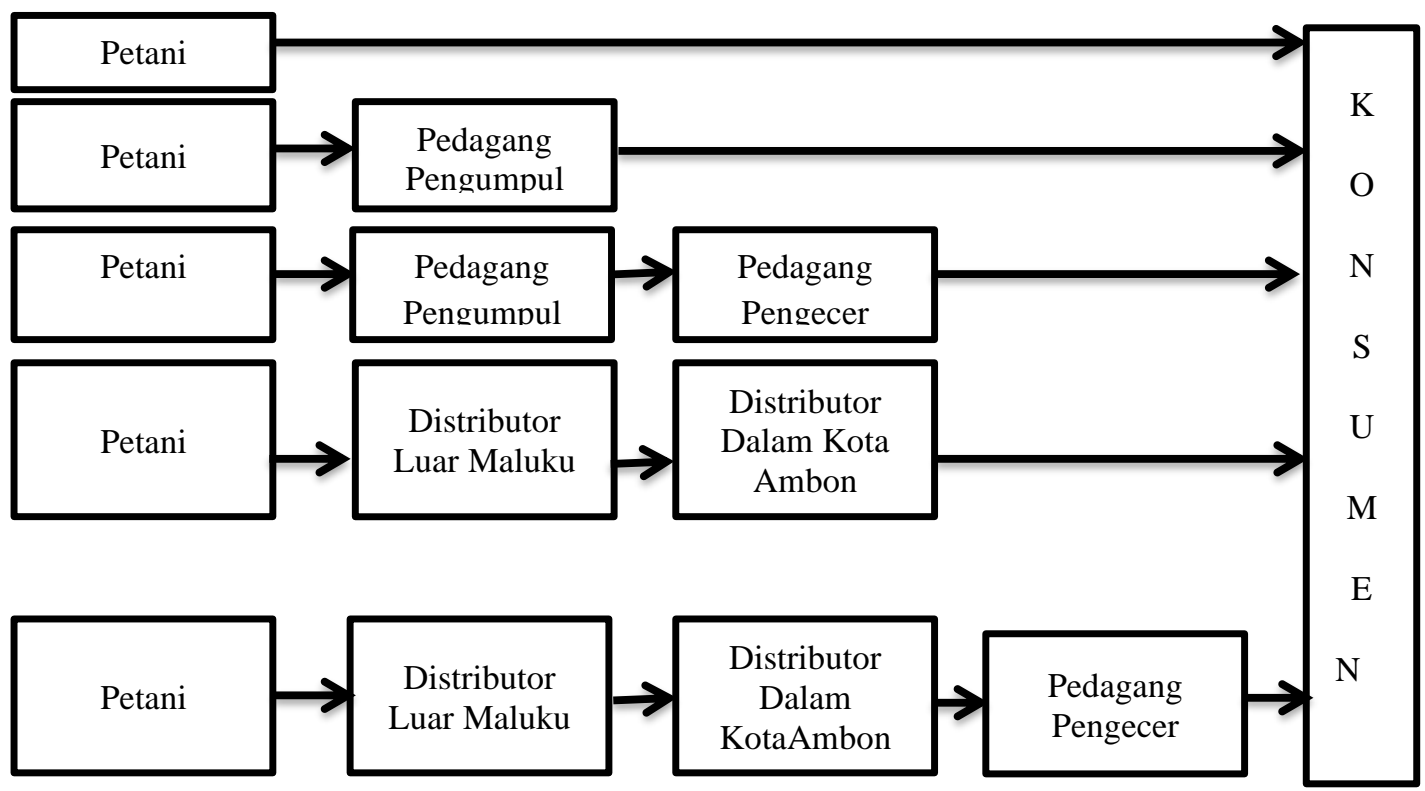

Sumber: Salampessy et al. (2019)

Gambar 1. Rantai pasar cabai rawit dan bawang merah di Kota Ambon 
Tabel 2. Margin pemasaran cabai rawit dan bawang merah pada rantai pasar I

\begin{tabular}{clrclcc}
\hline \multirow{2}{*}{ No } & \multicolumn{3}{c}{ Cabai Rawit } & \multicolumn{3}{c}{ Bawang Merah } \\
\cline { 2 - 7 } & \multicolumn{1}{c}{$\begin{array}{c}\text { Lembaga } \\
\text { Pemasaran }\end{array}$} & $\begin{array}{c}\text { Harga } \\
(\mathrm{Rp} / \mathrm{Kg})\end{array}$ & Share (\%) & Lembaga Pemasaran & Harga (Rp/Kg) & \multirow{2}{*}{ Share (\%) } \\
\hline 1 & Petani (harga jual & 47.666 & 100 & Petani & 28.633 & 100 \\
2 & Konsumen & 47.666 & 100 & Konsumen & 28.633 & 100 \\
& a. Biaya kemasaan & 80,00 & & a. Biaya kemasan & 80,00 & \\
& Karung & 80,00 & & Karung & 80,00 & 9 \\
& b. Total Biaya & 47.586 & 99,83 & b. Total Biaya & 28.553 & 99,72 \\
\hline
\end{tabular}

Sumber: Data primer 2019, diolah.

Tabel 3. Margin pemasaran pada rantai pasar II

\begin{tabular}{llcclcc}
\hline & \multicolumn{2}{c}{ Cabai Rawit } & & \multicolumn{2}{c}{ Bawang Merah } \\
\cline { 2 - 6 } & \multicolumn{1}{c}{ Lembaga Pemasaran } & Harga $(\mathrm{Rp} / \mathrm{Kg})$ & Share $(\%)$ & Lembaga Pemasaran & $\begin{array}{c}\text { Harga } \\
(\mathrm{Rp} / \mathrm{Kg})\end{array}$ & Share $(\%)$ \\
\hline 1 & Petani & 47.666 & 97,78 & Petani & 28,633 & 96,65 \\
2 & Pedagang Pengumpul & & 87,18 & Pedagang Pengumpul & 85,65 \\
& a. Harga Beli & 42.500 & & a. harga beli & 25,375 & \\
& b. Biaya Transportasi & 405.83 & & b. biaya transportasi & 194,92 \\
& c. Biaya Retribusi & 477.01 & & c. biaya retribusi & 233,90 \\
d. Biaya Kemasan & 178.87 & & d. biaya kemasan & 137,54 \\
e. Total Biaya & 1.061 .71 & & e. Total Biaya & 566,36 \\
& f. Keuntungan & 47.688 & 97,82 & f. keuntungan & 29.059 & 98,09 \\
\hline
\end{tabular}

Sumber: Data primer 2019, diolah.

Tabel 4. Margin pemasaran pada rantai pasar III

\begin{tabular}{|c|c|c|c|c|c|c|}
\hline \multirow{2}{*}{ No } & \multicolumn{3}{|c|}{ Cabai Rawit } & \multicolumn{3}{|c|}{ Bawang Merah } \\
\hline & Lembaga Pemasaran & $\operatorname{Harga}(\mathrm{Rp} / \mathrm{Kg})$ & Share $(\%)$ & Lembaga Pemasaran & Harga $(\mathrm{Rp} / \mathrm{Kg})$ & Share $(\%)$ \\
\hline 1 & Petani & 47.666 & 79,44 & Petani & 28.633 & 81,64 \\
\hline 2 & Pedagang Pengumpul & & 81,25 & Pedagang Pengumpul & & 84.46 \\
\hline & a. Harga Beli & 42.500 & & a. harga beli & 25.375 & \\
\hline & b. Biaya Transportasi & 405,83 & & b. biaya transportasi & 194,92 & \\
\hline & c. Biaya Retribusi & 477,01 & & c. biaya retribusi & 233,90 & \\
\hline & d. Biaya Kemasan & 178,87 & & d. biaya kemasan & 137,54 & \\
\hline & e. Harga Jual & 48.750 & & e. harga jual & 29.625 & \\
\hline & f. Total Biaya & $1.061,71$ & & Total Biaya & 566,36 & \\
\hline & g. Keuntungan & $47.688,29$ & 97,82 & g. keuntungan & $29.058,64$ & 98,09 \\
\hline & margin pemasaran & 6.250 & & margin pemasaran & 4.250 & \\
\hline 3 & Pedagang Pengencer & & 100 & Pedagang Pengencer & & 100 \\
\hline & a. harga beli & 46.703 & & a. harga beli & 26.037 & \\
\hline & b. biaya transportasi & $3.268,96$ & & b. biaya transportasi & $2.016,11$ & \\
\hline & c. biaya retribusi & $1.304,52$ & & c. biaya retribusi & 708,14 & \\
\hline & d. biaya kemasan & 654,11 & & d. biaya kemasan & 393,69 & \\
\hline & e. harga jual (ke konsumen) & 60.000 & & e. harga jual & $35.074,00$ & \\
\hline & f. Total Biaya & $5.227,59$ & & f. Total Biaya & $3.117,94$ & \\
\hline & g. keuntungan & $54.772,41$ & & g. keuntungan & $31.956,06$ & \\
\hline & margin pemasaran & 13.297 & & margin pemasaran & 9.037 & \\
\hline
\end{tabular}

Sumber: Data primer 2019, diolah. 
Rantai pasar II (petani-pedagang pengumpul) memperlihatkan bahwa margin pemasaran kedua komoditi masing-masing $\mathrm{Rp} 6.250,-/ \mathrm{kg}$ dan $\mathrm{Rp} 4.250$,$/ \mathrm{kg}$. Persentasi keuntungan pedagang pengumpul untuk penjualan kedua komoditi adalah 97,82 persen dan 98,09 persen. Keuntungan peamsaran untuk kedua komoditi lebih rendah disebabkan besarnya biaya yang dikeluarkan pedagang. Di sisi lain, share yang diperoleh petani lebih tinggi dibandingkan share yang diperoleh pedagang pengumpul. Hal ini dikarenakan harga jual kedua komoditi ke pedagang pengumpul lebih rendah dibandingkan harga jual petani ke konsumen.

Rantai pasar III menunjukkan bahwa pedagang pengecer mempunyai keuntungan lebih besar dibandingkan pedagang pengumpul, dikarenakan biaya pemasaran yang dikeluarkan pengecer lebih rendah. Selain itu, harga jual di tingkat pengecer lebih tinggi dibandingkan harga jual pedagang pengumpul. Margin yang diperoleh pedagang pengumpul untuk kedua komoditi pada Rantai pasar III sebesar Rp. 6.250,-/kg dan Rp. 4.250,-/kg. Margin pemasaran yang diperoleh pedagang pengecer untuk kedua komoditi masingmasing sebesar Rp. 13.297,- dan Rp. 93.027,-.

Rantai pasar IV memperlihatkan bahwa margin pemasaran cabai rawit yang diperoleh distributor luar Maluku untuk kedua komoditi lebih rendah dibandingkan margin pemasaran yang diperoleh distributor di Kota Ambon. Selain itu, margin keuntungan yang diperoleh distributor luar Maluku untuk kedua komoditi lebih rendah dari margin keuntungan yang diperoleh distributor di Kota Ambon. Hal ini dikarenakan harga rendah, biaya yang dikeluarkan distributor di luar Maluku lebih besar dari distributor yang berada di Kota Ambon.

Tabel 5 menunjukkan bahwa ada perbedaan margin pemasaran maupun keuntungan yang diperoleh dari setiap pelaku pasar pada rantai pasar V. Margin keuntungan terbesar dari ketiga lembaga pemasaran diproleh pedagang pengecer untuk kedua komoditi.

Tabel 6 menunjukkan bahwa keuntungan terbesar diperoleh dari ketiga lembaga pemasaran yakni distributor di luar Maluku. Untuk bawang merah, margin pemasaran yang diperoleh distributor di Kota Ambon lebih kecil dari margin pemasaran distributor di Luar Maluku. Hal ini dikarenakan adanya perbedaan harga beli serta harga jual diantara kedua lembaga pemasaran.

\section{Farmer Share}

Bagian atau persentase yang diperoleh petani melalui kesepakatan harga jual dan harga beli dengan pedagang maupun konsumen dikenal dengan Farmer share. Oleh karena itu, perbedaan share yang diterima petani merupakan bagian dari adanya perbedaan harga jual ditingkat pedagang maupun distributor ke konsumen. Berdasarkan analisis margin di atas, share yang diperoleh petani cabai tertinggi yakni pada rantai pasar I (petani - konsumen). Sementara share terkecil yang diperoleh yakni pada rantai pasar IV. Berikut share yang diperoleh petani dari kelima eantai pasar cabai dan bawang merah ditampilkan pada Tabel 7 dan 8 .

Tabel 5. Margin pemasaran pada rantai pasari IV

\begin{tabular}{|c|c|c|c|c|c|c|}
\hline \multirow{2}{*}{ No } & \multicolumn{3}{|c|}{ Cabai Rawit } & \multicolumn{3}{|c|}{ Bawang Merah } \\
\hline & Lembaga Pemasaran & $\operatorname{Harga}(\mathrm{Rp} / \mathrm{Kg})$ & Share $(\%)$ & Lembaga Pemasaran & $\operatorname{Harga}(\mathrm{Rp} / \mathrm{Kg})$ & Share $(\%)$ \\
\hline \multirow[t]{2}{*}{1} & Petani & & 87.61 & & & 72.00 \\
\hline & Harga Jual & 35.000 & & Harga Jual & 18.000 & \\
\hline \multirow[t]{9}{*}{2} & Distributor Luar & & & Distributor Luar & & \\
\hline & Maluku & & & Maluku & & \\
\hline & Harga Beli & 35.000 & & Harga Beli & 18.000 & \\
\hline & a. biaya transportasi & 2.500 & & a. biaya transportasi & 2.500 & \\
\hline & b. biaya kemasan & 1.000 & & b. biaya kemasan & 1.000 & \\
\hline & c. harga jual & 41.875 & & c. harga jual & 23.285 & \\
\hline & d. total biaya & 3.500 & & d. total biaya & 3.500 & \\
\hline & f. keuntungan & 31.500 & 75.22 & f. keuntungan & 19.785 & 84.97 \\
\hline & margin pemasaran & 6.875 & & margin pemasaran & 5.285 & \\
\hline \multirow[t]{10}{*}{3} & Distributor Kota & & & Distributor Kota & & \\
\hline & Ambon & & 100 & Ambon & & 100 \\
\hline & a. harga beli & 41.875 & & a. harga beli & 23.285 & \\
\hline & b. biaya transportasi & 165,39 & & b. biaya transportasi & 158,85 & \\
\hline & c. biaya retribusi & 88,26 & & c. biaya retribusi & 79,69 & \\
\hline & d. biaya kemasan & 76,41 & & d. biaya kemasan & 75,52 & \\
\hline & e. harga jual & 48.125 & & e. harga jual & 25.000 & \\
\hline & f. Total Biaya & 330,06 & & f. Total Biaya & 314,06 & \\
\hline & f. keuntungan & $47.794,94$ & 99.31 & f. keuntungan & $24.685,94$ & 98.74 \\
\hline & margin pemasaran & 6.250 & & margin pemasaran & 1.715 & \\
\hline
\end{tabular}


Tabel 6. Margin pemasaran pada rantai pasar V

\begin{tabular}{|c|c|c|c|c|c|c|}
\hline \multirow{2}{*}{ No } & \multicolumn{3}{|c|}{ Cabai Rawit } & \multicolumn{3}{|c|}{ Bawang Merah } \\
\hline & Lembaga Pemasaran & Harga $(\mathrm{Rp} / \mathrm{Kg})$ & Share $(\%)$ & Lembaga Pemasaran & Harga $(\mathrm{Rp} / \mathrm{Kg})$ & Share $(\%)$ \\
\hline \multirow[t]{2}{*}{1} & Petani & & 71,79 & & & 60,76 \\
\hline & Harga Jual & 35.000 & & Harga Jual & 18.000 & \\
\hline \multirow[t]{8}{*}{2} & $\begin{array}{l}\text { Distributor Luar } \\
\text { Maluku }\end{array}$ & & & $\begin{array}{l}\text { Distributor Luar } \\
\text { Maluku }\end{array}$ & & \\
\hline & Harga Beli & 35.000 & & Harga Beli & 18.000 & \\
\hline & a. biaya transportasi & 2.500 & & a. biaya transportasi & 2.500 & \\
\hline & b. biaya kemasan & 1.000 & & b. biaya kemasan & 1.000 & \\
\hline & c. harga jual & 41.875 & & c. harga jual & 23.285 & \\
\hline & d. total biaya & 3.500 & & d. total biaya & 3.500 .00 & \\
\hline & f. keuntungan & 31.500 & 75,22 & f. keuntungan & 19.785 & 84,97 \\
\hline & margin pemasaran & 6.875 & & margin pemasaran & 5.285 & \\
\hline \multirow[t]{9}{*}{3} & $\begin{array}{l}\text { Distributor } \\
\text { Kota Ambon }\end{array}$ & & 98,72 & $\begin{array}{l}\text { Distributor } \\
\text { Kota Ambon }\end{array}$ & & 93,14 \\
\hline & a. harga beli & 41.875 & & a. harga beli & 23.285 & \\
\hline & b. biaya transportasi & 165,39 & & b. biaya transportasi & 158,85 & \\
\hline & c. biaya retribusi & 88,26 & & c. biaya retribusi & 79,69 & \\
\hline & d. biaya kemasan & 76,41 & & d. biaya kemasan & 75,52 & \\
\hline & e. harga jual & 48.125 & & e. harga jual & 25.000 & \\
\hline & f. Total Biaya & 330,06 & & f. Total Biaya & 314,06 & \\
\hline & f. keuntungan & $47.794,94$ & 99,31 & f. keuntungan & $24.685,94$ & 98,74 \\
\hline & margin pemasaran & 6.250 & & margin pemasaran & 1.715 & \\
\hline \multirow[t]{9}{*}{4} & Pedagang Pengecer & & 100 & Pedagang Pengecer & & 100 \\
\hline & a. harga beli & 42.500 & & a. harga beli & 25.375 & \\
\hline & b. biaya transportasi & 1.375 & & b. biaya transportasi & 379,77 & \\
\hline & c. biaya retribusi & 693,75 & & c. biaya retribusi & 165,45 & \\
\hline & d. biaya kemasan & 270,83 & & d. biaya kemasan & 102,52 & \\
\hline & e. harga jual & 48.750 & & e. harga jual & 29.625 & \\
\hline & f. Total Biaya & $2.339,58$ & & f. Total Biaya & 647,74 & \\
\hline & f. keuntungan & $46.410,42$ & 95,20 & f. keuntungan & $28.977,26$ & 97,81 \\
\hline & Margin Pemasaran & 6.250 & & Margin Pemasaran & 4.250 & \\
\hline
\end{tabular}

Tabel 7. Share yang diperoleh petani cabai rawit pada ke-V rantai pasar

\begin{tabular}{cccc}
\hline Rantai pasar & Harga Ditingkat Petani $(\mathrm{Rp} / \mathrm{Kg})$ & Harga Ditingkat Konsumen & Share $(\%)$ \\
\hline I & 47.666 & 47.666 & 100 \\
II & 42.500 & 48.750 & 87,18 \\
III & 46.703 & 60.000 & 77,84 \\
IV & 35.000 & 47.795 & 73,23 \\
V & 35.000 & 46.410 & 75,41 \\
\hline
\end{tabular}

Sumber: Data primer 2019, diolah.

Tabel 8. Share yang diperoleh petani bawang merah pada ke-V rantai pasar

\begin{tabular}{cccc}
\hline Rantai pasar & Harga Ditingkat Petani $(\mathrm{Rp} / \mathrm{Kg})$ & Harga Ditingkat Konsumen & Share $(\%)$ \\
\hline I & 28.633 & 28.633 & 100 \\
II & 25.375 & 29.625 & 85,65 \\
III & 26.037 & 35.074 & 74,23 \\
IV & 18.000 & 29.625 & 60,76 \\
V & 18.000 & 25.000 & 72,00 \\
\hline
\end{tabular}

Sumber: Data primer 2019, diolah. 
Tabel 9. Hasil uji secara simultan faktor yang mempengaruhi harga cabai rawit dan bawang merah di tingkat eceran di Kota Ambon.

\begin{tabular}{lcccc}
\hline \multicolumn{1}{c}{ Komoditi } & Nilai Sig & $\mathrm{F}_{\text {Hitung }}$ & $\mathrm{F}_{\text {Tabel }}$ & Keterangan \\
\hline Cabai Rawit & 0,001 & 9,563 & 2,40 & $\mathrm{~F}_{\text {Hitung }}>\mathrm{F}_{\text {Tabel }}$ \\
Bawang Merah & 0,001 & 7,838 & 2,40 & $\mathrm{~F}_{\text {Hitung }}>\mathrm{F}_{\text {Tabel }}$ \\
\hline
\end{tabular}

Sumber: Data Primer 2019, diolah.

Tabel 7 menunjukkan bahwa harga tertinggi cabai rawit ditingkat petani yakni pada rantai pasar I dan III. Terlihat bahwa semakin banyak pelaku pasar yang terlibat dalam distribusi cabai rawit, maka semakin kecil share yang diperoleh petani. Share terendah yang diperoleh petani pada rantai pasar IV dan rantai pasar V. Hal ini disebabkan perbedaan harga beli dan harga jual.

Tabel 8 menunjukkan bahwa terdapat perbedaan persentase yang diterima petani dari setiap rantai pasar. Share tertinggi yang diperoleh petani bawang merah yakni pada rantai pasar I (petani - konsumen) dan rantai pasar II. Share terendah pada rantai pasar IV dan V.

Berdasarkan analisis pemasaran terlihat perbedaan harga ditingkat konsumen oleh pelaku pasar (pedagang pengumpul, pedagang pengecer dan distributor). Adanya kenaikan harga yang cukup signifikan di tingkat konsumen, namun tidak diikuti oleh harga di tingkat produsen di Kota Ambon.

Pola distribusi terhadap kedua komoditi yang panjang mendorong terjadinya perbedaan harga pada pelaku distribusi. Perbedaan harga jual disebabkan oleh perbedaan biaya pada tiap pelaku distribusi. Perbedaan biaya yang dikeluarkan distributor akan mendorong pembentukan harga jual kedua komoditi yang berbeda, dalam hal ini harga akan meningkat pada setiap rantai distribusi. Peningkatan harga jual pada setiap lembaga distributor akan mendorong pembentukan harga cabai rawit dan bawang merah yang semakin tinggi di tingkat konsumen akhir. Harga jual yang semakin tinggi di pasar secara langsung memengaruhi daya beli konsumen (masyarakat pada umumnya).

\section{Analisis Faktor yang Berpengaruh Terhadap Pembentukan Harga Cabai Rawit dan Harga Bawang Merah}

\section{Analisis Pembentukan Harga Cabe Rawit Uji Koefisien Determinasi}

Hasil analisis faktor biaya transportasi $\left(X_{1}\right)$, retribusi $\left(X_{2}\right)$, kemasan $\left(X_{3}\right)$, daya beli konsumen $\left(X_{4}\right)$, selisih pasokan dan permintaan $\left(X_{5}\right)$, produksi $\left(X_{6}\right)$, barang subtitusi $\left(X_{7}\right)$ dan variabel dummy gangguan distribusi atau cuaca buruk $\left(D_{1}\right)$ diperoleh nilai koefisien $\mathrm{R}^{2} 78,4$ untuk cabai rawit dan 74,1 untuk bawang merah. Hal ini menunjukkan bahwa sebesar 78,4 persen dan 74,1 persen pembentukan harga cabai rawit dan bawang merah di tingkat eceran dapat dijelaskan oleh biaya transportasi $\left(X_{1}\right)$, retribusi $\left(X_{2}\right)$, kemasan $\left(X_{3}\right)$, daya beli konsumen $\left(X_{4}\right)$, selisih pasokan dan permintaan $\left(X_{5}\right)$, produksi $\left(X_{6}\right)$, barang subtitusi $\left(X_{7}\right)$ dan variabel dummy gangguan distribusi atau cuaca buruk $\left(D_{1}\right)$, sisanya dijelaskan variabel lain yang tidak ada dalam model.

\section{Uji Simultan (Uji F)}

Hasil uji F secara simultan pada tingkat kepercayaan 95 persen $(0,05)$ memperlihatkan nilai $F_{\text {hitung }}$ kedua variabel dependen lebih besar dari nilai $F_{\text {tabel }}$. Artinya semua variabel yang diteliti yaitu biaya transportasi $\left(X_{1}\right)$, retribusi $\left(X_{2}\right)$, kemasan $\left(X_{3}\right)$, daya beli konsumen $\left(X_{4}\right)$, selisih pasokan dan permintaan $\left(X_{5}\right)$, produksi $\left(X_{6}\right)$, barang subtitusi $\left(X_{7}\right)$ dan variabel dummy gangguan distribusi atau cuaca buruk $\left(D_{1}\right)$ berpengaruh siginifikan terhadap pembentukan harga kedua komoditi. Tabel 9 menampilkan hasil analisis faktor yang mempengaurhi harga cabai rawit dan bawang merah di tingkat eceran.

\section{Uji Parsial (Uji T)}

\section{Transportasi $\left(X_{1}\right)$}

Nilai peluang transportasi $0,002<0,05$, nilai $t_{\text {hitung }}$ sebesar 3.106 lebih besar dari nilai tabel yakni 2,05, menunjukkan bahwa transportasi berpengaruh terhadap pembentukan harga cabai ditingkat eceran. Koefisien regresi transportasi sebesar 0,213 artinya jika transportasi naik satu rupiah maka harga cabe rawit akan mengalami kenaikan sebesar 0,213 rupiah. Tingginya transportasi menjadi penyebab harga komoditi cabai rawit meningkat. Hal ini terjadi apabila pedagang harus membeli produk cabai rawit dari luar daerah kemudian di pasarkan di Kota Ambon.

\section{Retribusi $\left(X_{2}\right)$}

Nilai peluang retribusi $0,512>0,05$, nilai $t_{\text {hitung }}$ sebesar 0,916 lebih kecil dari nilai $t_{\text {tabel }} 2,05$. Artinya retribusi tidak berpengaruh terhadap pembentukan harga cabai rawit ditingkat eceran. Koefisien regresi sebesar 0,034, artinya apabila terjadi kenaikan retribusi sebesar Rp. 1.00-, maka harga cabai rawit ditingkat eceran akan meningkat sebesar Rp. 0,034 per kg. Hal ini dikarenakan selama ini retribusi pasar tidak menjadi beban bagi pedagang dikarenakan biaya retribusi pasar sebesar Rp 2.000-5.000 per hari. Pedagang diwajibkan membayar retribusi pasar setiap hari kepada pengelola pasar. Retribusi digunakan sebagai biaya operasional pengelola pasar untuk menjaga kebersihan, keamanan dan penataan pasar.

\section{Kemasan $\left(X_{3}\right)$ \\ Nilai peluang kemasan $0,004<0,05$, nilai $t_{\text {hitung }}$ sebesar 2.306 lebih besar dari nilai $t_{\text {tabel }}$ yakni 2,05. Hal}


ini menunjukan bahwa kemsasan berpengaruh terhadap pembentukan harga cabai rawit ditingkat eceran. Nilai koefisien sebesar 0,116, artinya jika terjadi kenaikan biaya kemasan sebesar Rp. 1,00-, maka harga cabai ditingkat eceran akan meningkat sebesar Rp. 0,116 per $\mathrm{kg}$. Kemasan yang digunakan adalah karung plastik dan kantong plastik. Kedua kemasan ini digunakan pedagang sebagai wadah untuk menyimpan dan mengemas produk yang dibeli pembeli. Apabila terjadi kenaikan harga kemasan sekalipun sedikit maka akan merangsang kenaikan harga jual cabe rawit.

\section{Daya Beli Konsumen $\left(X_{4}\right)$}

Nilai peluang daya beli konsumen 0,204 > 0,05, nilai $t_{\text {hitung }} 1.009$ lebih kecil dari nilai $t_{\text {tabel }} 2,05$. Hal ini menunjukan bahwa daya beli konsumen tidak berpengaruh terhadap pembentukan harga cabai rawit ditingkat eceran. Koefisien regresi sebesar 0,019, berarti jika terjadi kenaikan daya beli konsumen sebesar Rp. 1,00-, maka harga cabai ditingkat eceran akan meningkat sebesar Rp. 0,019. per kg. Daya beli konsumen tidak berpengaruh terhadap pembentukan harga eceran cabe rawit, dikarenakan daya beli konsumen bervariasi tergantung besaran nilai yang dibayarkan dan pendapatan konsumen. Jika tingkatan pendapatan konsumen bertambah memungkinkan mereka akan membeli cabe rawit sekalipun harganya mahal, sebaliknya jika pendapatan rendah maka maka konsumen tidak akan membelanjakan uangnya untuk cabe rawit dalam jumlah besar.

\section{Selisih Pasokan dan Permintaan Cabai Rawit $\left(X_{5}\right)$}

Nilai peluang selisih pasokan dan permitaan cabae rawit $0,031<0,05$, nilai thitung 2,219 lebih besar dari nilai $t_{\text {tabel }} 2,05$. Artinya selisih pasokan dan permintaan cabai rawit berpengaruh terhadap pembentukan harga cabai rawit ditingkat eceran. Nilai koefisien sebesar 0,471 , apabila terjadi kenaikan gap (selisih pasokan dan permintaan) cabai rawit sebesar Rp. 1,00-, maka harga cabai rawit ditingkat eceran akan meningkat sebesar Rp. 0,471 per kg. Produksi yang rendah menjadi penyebab kenaikan harga cabai rawit di Kota Ambon terutama pada saat-saat tertentu (hari raya dan sebagainya), yang disebabkan adanya gap pasokan dan permintaan. Oleh karena itu, produksi yang rendah mempunyai dampak yang besar terhadap kenaikan harga cabai rawit di Kota Ambon.

\section{Produksi $\left(X_{6}\right)$}

Nilai peluang produksi $0,251>0,05$, nilai thitung 0,967 lebih kecil dari nilai $t_{\text {tabel }} 2,05$. Produksi cabai rawit tidak berpengaruh terhadap pembentukan harga cabai ditingkat eceran. Koefisien regresi 0,058, apabila terjadi kenaikan produksi cabai sebesar Rp. 1,00-, maka harga cabai ditingkat eceran akan meningkat sebesar Rp. 0,058 per kg. Produksi tidak berpengaruh terhadap harga eceran cabe rawit di pasaran. Penawaran produk akan dilakukan pedagang berdasarkan jumlah produksi yang tersedia. Jika harga produk naik maka jumlah ditawarkan meningkat sebaliknya jika harga produk turun maka jumlah ditawarkan menurun. Produksi cabe rawit tidak berpengaruh terhadap harga eceran dikarenakan pasokan cabe rawit tidak hanya di dalam Kota Ambon tetapi juga dari luar Kota Ambon. Oleh sebab itu jika produksi tersedia melimpah berarti harga akan mengalami penurunan dan sebaliknya jika produksi sedikit maka harga akan mengalami peningkatan.

\section{Barang Subtitusi $\left(X_{7}\right)$}

Nilai peluang $0,105>0,05$, nilai thitung 0,147 lebih kecil dari nilai $t_{\text {tabel }} 2,05$. Artinya barang substitusi tidak berpengaruh terhadap pembentukan harga cabai ditingkat eceran. Koefisien regresi 0,029, apabila terjadi kenaikan barang substitusi sebesar Rp. 1,00-, maka harga cabai ditingkat eceran akan meningkat sebesar Rp. 0,029 per $\mathrm{kg}$. Hasil analisis terlihat bahwa barang subtitusi tidak berpangaruh terhadap harga eceran cabe rawit. Hal ini berarti berapapun harga cabe rawit, konsumen tetap membelinya karena merupakan bahan kebutuhan pokok yang dipakai untuk konsumsi setiap hari. Konsumen setiap hari melakukan permintaan terhadap cabe rawit dan tidak melakukan permintaan terhadap barang substitusi.

\section{Dummy Gangguan Distribusi atau Cuaca Buruk $\left(D_{1}\right)$} Nilai peluang $0,308>0,05$, nilai thitung 0,098 lebih kecil dari nilai $t_{\text {tabel }} 2,05$. Hal ini menunjukan bahwa dummy gangguan distribusi atau cuaca buruk tidak berpengaruh terhadap pembentukan harga cabai rawit ditingkat eceran. Apabila terjadi gangguan distribusi atau cuaca, maka harga cabai rawit ditingkat eceran meningkat. Maluku secara umum sebagai wilayah kepulauan, pengaruh cuaca buruk tidak hanya berdampak pada kenaikan harga cabai rawit di Kota Ambon, akan tetapi akan berdampak pada kenaikan harga secara umum di semua wilayah di Maluku. Hal ini dikarenakan distribusi cabai rawit yang tidak merata akibat cuaca buruk (terutama musim pancaroba). Harga yang rendah disebabkan terjadinya over product di Kota Ambon dan wilayah sekitar yang menjadi produsen sebagai akibat cuaca buruk sehingga tidak dapat mendistribusikan cabai rawit ke wilayah lain di Maluku. Hal ini juga dapat merugikan petani dan pedagang di Kota Ambon.

\section{Analisis Pembentukan Harga Bawang Merah}

\section{Uji Parsial (Uji T) \\ Transportasi $\left(X_{1}\right)$}

Nilai peluang $0,012<0,05$, nilai $t_{\text {hitung }} 2,607$ lebih besar dari nilai $t_{\text {tabel }} 2,05$. Transportasi berpengaruh terhadap pembentukan harga bawang merah ditingkat eceran. Koefisien regresi transportasi sebesar 0,336 artinya apabila transportasi naik satu rupiah maka harga bawang merah akan mengalami kenaikan sebesar 0,336 rupiah. Transportasi berpengaruh terhadap pembentukan harga bawang merah dikarenakan apabila tranportasi mengalami kenaikan maka harga eceran akan mengalami kenaikan. Oleh sebab itu transportasi menjadi penting dalam pendistribusian barang dari petani ke produsen, kemudian produsen ke konsumen. Distribusi bawang 
merah dari luar Ambon membutuhkan transportasi, sehingga berpengaruh terhadap pembentukan harga eceran di tingkat eceran.

\section{Retribusi $\left(X_{2}\right)$}

Nilai peluang $0,176>0,05$, nilai thitung 1,035 lebih kecil dari nilai $t_{\text {tabel }} 2,05$. Retribusi tidak berpengaruh terhadap pembentukan harga cabai ditingkat eceran. Koefisien regresi sebesar 0,145, apabila terjadi kenaikan retribusi sebesar Rp. 1,00-, maka harga bawang merah ditingkat eceran akan meningkat sebesar Rp. 0,145 per kg. Retribusi pasar dibayarkan pedagang kepada pengelola pasar. Retribusi berbeda-beda menurut tempat/lokasi penjualan. Retribusi pasar berkisar Rp 2.000-5.000 per hari. Retribusi pasar tidak berpengaruh karena berapapun biayanya, pedagang harus membayar retribusi sebagai biaya untuk menduduki tempat berdagang di pasar. Apabila terjadi kenaikan retribusi maka pedagang akan menaikan harga eceran bawang merah sekalipun nilainya lebih rendah. Hal ini dilakukan karena pedagang terkadang tidak mau mengalami kerugian sekalipun kecil.

\section{$\operatorname{Kemasan}\left(X_{3}\right)$}

Nilai peluang $0,572>0,05$, nilai thitung 0,794 lebih kecil dari nilai $t_{\text {tabel }} 2,05$. Biaya kemasan tidak berpengaruh terhadap pembentukan harga bawang merah ditingkat eceran. Koefisien 0,211, apabila terjadi kenaikan biaya kemasan sebesar Rp. 1,00-, maka harga bawang merah ditingkat eceran akan meningkat sebesar Rp. 0,211 per kg. Kenaikan harga kemasan sekalipun kecil tetap merangsang kenaikan harga komoditi. Kemasan tidak berpengaruh karena pedagang membeli kemasan dalam jumlah besar sebagai persediaan salama proses transaksi jual beli. Namun apabila biaya kemasan meningkat, maka harga eceran akan mengalami peningkatan.

\section{Daya Beli Konsumen $\left(X_{4}\right)$}

Nilai peluang $0,312>0,05$, nilai $t_{\text {hitung }} 1,126$ lebih kecil dari nilai $t_{\text {tabel }} 2,05$. Daya beli konsumen tidak berpengaruh terhadap pembentukan harga bawang merah ditingkat eceran. Koefisien 0,124 , apabila terjadi kenaikan daya beli konsumen sebesar Rp. 1,00-, maka harga bawang merah ditingkat eceran akan meningkat sebesar Rp. 0,124 per kg. Daya beli konsumen terhadap komoditi bawang merah tergantung pendapatan. Daya beli konsumen berbeda-beda berdasarkan tingkatan pendapatan konsumen. Jika pendapatan konsumen naik, maka jumlah bawang merah yang dibeli naik dan sebaliknya. Daya beli tidak berpengaruh dikarenakan berapun harga eceran bawang merah, konsumen tetap membeli produk tersebut.

Selisih Pasokan dan Permintaan Bawang Merah $\left(X_{\mathbf{5}}\right)$ Nilai peluang $0,002<0,05$, nilai thitung 2,724 lebih besar dari nilai $t_{\text {tabel }} 2,05$. Selisih pasokan dan permintaan bawang merah berpengaruh terhadap pembentukan harga bawang merah ditingkat eceran. Koefisien regresi 0,476, apabila terjadi kenaikan gap (selisih pasokan dan permintaan) bawang merah sebesar Rp. 1,00-, maka harga bawang merah ditingkat eceran akan meningkat sebesar Rp. 0,476 per kg. Selisih pasokan dan permintaan bawang merah menunjukkan bahwa berapa besar pasokan bawang merah dalam Kota Ambon dan luar Ambon dengan permintaan konsumen. Terlihat bahwa pasokan dari dalam maupun luar Ambon tidak mencukupi permintaan konsumen, apalagi terjadi pada hari-hari besar keagamaan dan hari besar lainnya. Hal inilah yang menyebabkan terjadinya kenaikan harga pada tingkat pedagang eceran.

\section{Produksi $\left(X_{6}\right)$}

Nilai peluang $0,046<0,05$, nilai $t_{\text {hitung }} 2,418$ lebih besar dari nilai $t_{\text {tabel }}$ 2,05. Produksi bawang merah berpengaruh terhadap pembentukan harga bawang merah ditingkat eceran. Koefisien regresi 0,134, apabila terjadi kenaikan produksi bawang merah sebesar Rp. 1,00-, maka harga bawang merah ditingkat eceran akan meningkat sebesar Rp. 0,134 per kg. Produksi berpengaruh terhadap pembentukan harga eceran, hal ini terlihat bahwa ketika produksi meningkat diikuti oleh kenaikan harga bawang merah, maka pedagang akan memperoleh untung besar. Apabila produksi meningkat tetapi harga bawang mengalami penurunan maka pedagang tidak untung atau pulang pokok. Produksi bawang merah dalam Kota Ambon tidak mencukupi, oleh sebab itu sangat membutuhkan pasokan dari luar daerah untuk menjawab permintaan konsumen yang meningkat.

\section{Barang Subtitusi $\left(X_{7}\right)$}

Nilai peluang $0,032<0,05$, nilai thitung 2,431 lebih besar dari nilai $t_{\text {tabel }} 2,05$. Barang substitusi berpengaruh terhadap pembentukan harga bawang merah ditingkat eceran. Koefisien regresi 0,021, apabila terjadi kenaikan barang substitusi sebesar Rp. 1,00-, maka harga bawang merah ditingkat eceran akan meningkat sebesar Rp. 0,02 per kg. Barang substitusi berpengaruh signifikan terhadap harga eceran bawang merah. Jika harga bawang merah naik, konsumen akan beralih ke barang substitusi seperti bawang putih dan bawang bombai. Jika terjadi inflasi pada komoditi bawang merah, konsumen akan beralih untuk mengkonsumsi bawang putih dan bawang bombai sebagai bumbu penyedap masakan.

\section{Dummy Gangguan Distribusi atau Cuaca Buruk $\left(D_{1}\right)$}

Nilai peluang $0,149>0,05$, nilai $t_{\text {hitung }} 1,108$ lebih kecil dari nilai $t_{\text {tabel }} 2,05$. Dummy gangguan distribusi atau cuaca buruk tidak berpengaruh terhadap pembentukan harga bawang merah ditingkat eceran. Jika terjado gangguan distribusi atau cuaca maka harga bawang merah ditingkat eceran akan meningkat. Dummy gangguan distribusi atau cuaca buruk tidak berpengaruh terhadap pembentukan harga eceran dikarenakan sekalipun cuaca buruk, pasokan bawang merah tetap tersedia untuk menjawab permintaan konsumen sekalipun jumlah sedikit. Saat ini terlihat bahwa Ketika harga bawang merah naik, konsumen tetap membelinya 
karena kebutuhan bumbu masak menjadi prioritas dalam konsumsi rumah tangga.

\section{KESIMPULAN}

1. Petani cabai rawit dan bawang merah bertindak sebagai price taker, sedangkan pedagang pengumpul dan distributor yang membeli dari petani bertindak sebagai price maker.

2. Distributor dari luar Maluku terlibat dalam rantai pasar komoditi cabai rawit dan bawang merah, untuk menjaga persediaan guna memenuhi permintaan konsumen.

3. Analisis regresi menunjukan bahwa faktor-faktor yang memengaruhi pembentukan harga cabai rawit di tingkat eceran adalah transportasi (X1), kemasan (X3) dan selisih pasokan dan permintaan (X5), sedangkan faktor-faktor yang mempengaruhi pembentukan harga bawang merah di tingkat eceran adalah transportasi (X1), selisih pasokan dan permintaan (X5), Produksi (X6), dan barang substitusi (X7).

\section{DAFTAR PUSTAKA}

Ariningsih, E., dan M.K. Tentamia. 2004. Faktor-Faktor yang Mempengaruhi Penawaran dan Permintaan Bawang Merah di Indonesia. ICASERD. Working Paper No. 34.

BPS. 2019. Berita Resmi Statistik: Perkembangan Harga Indeks Konsumen/Inflasi. BPS

Hanafiah, A.M. dan A.M. Saefuddin. 2006. Tata Niaga Hasil Perikanan. UI-Press. Jakarta

Hidayat, F. 2013. Mengenal Gizi dan Nutrisi Bawang Merah. https://www.beritasatu.com/foodtravel/99123-mengenal-gizi-dan-nutrisi-bawangmerah.html.

Palar, N., P.A. Pangemanan, dan E.G. Tangkere. 2016. Faktor-faktor yang mempengaruhi harga cabai rawit dikota manado. Agri-Sosioekonomi: Jurnal Ilmiah Sosial Ekonomi Pertanian 12: 105-120.

Prastowo, N.J., T. Yanuarti, dan Y. Depari. 2008. Pengaruh distribusi dalam pembentukan harga komoditas dan implikasinya terhadap inflasi. Working paper Bank Indonesia. WP/07/2008.
Prastowo, N.J., Y. Tri, dan D. Yoni. 2011. Pengaruh Distribusi dalam Pembentukan Harga Komoditas dan Implikasinya terhadap Inflasi. Jakarta: Bank Indonesia.

Putri, R.M. 2016. Analisis Kinerja Pasar pada Pasar Induk Bawang Merah di Kecamatan Dringu Kabupaten Probolinggo. Skripsi. Program Studi Agribisnis, Fakultas Pertanian, Universitas Jember.

Ruslan, J.A. 2016. Transmisi Harga dan Perilaku Pasar Bawang Merah. Tesis. Sekolah Pasca Sarjana Institut Pertanian Bogor.

Sabarella, W.B. Komalasari, S. Wahyuningsih, M.D.N. Saida, M. Manurung, Sehusman, Rinawati, dan Y. Supriyati. 2019. Buletin Konsumsi Pangan. Pusat Data dan Sistem Informasi Pertanian Sekretariat Jenderal Kementerian Pertanian. Buletin Konsumsi 10 (1).

Salampessy, Y.E., N.R. Timisela, dan Y.M.T.N. Apituley. 2019. Saluran pemasaran cabai rawit dan bawang merah di Kota Ambon. Jurnal Agrilan 7: 255-263.

Setiadi. 2008. Bertanam Cabai. Jakarta: Penebar Swadaya. 183 hal.

Soepatini, I. Muhammad, S. Anton, dan N. Sidiq. 2017. Model Kebijakan Distribusi Bawang Merah dan Putih di Wilayah Eks Karesidenan Surakarta dengan Supply Chain Management. The 5th Urecol Proceeding. UAD, Yogyakarta.

Sugiyono. 2011. Metode Penelitian Kuantitatif, Kualitatif dan R \& D. Bandung: Alfabeta.

van Der Vorst, J.G.A.J. 2004. Supply Chain Management: Theory and Practice. In: Camps, T., P. Diederen, G.J. Hofstede, and B. Vos. (Eds.). The Emerging World of Chains \& Networks. Hoofdstuk: Elsevier.

Wahyudi, H.D., Soepatini, Syamsudin, dan A. Nuryulia. 2018. Analisis Pembentukan Harga Komoditas Cabai di Surakarta. Prosiding: The National Conferences Management and Business (NCMAB) 2018 "Pemberdayaan dan Penguatan Daya Saing Bisnis Dalam Era Digital”.

Yuliawati, F. 2019. Faktor-faktor yang mempengaruhi harga cabai rawit di pasar Ngablak, Kabupaten Magelang. Jurnal SEPA 15: 164-171. 